\title{
ХАРАКТЕРИСТИКА СУБ'СКТА ОРГАНІЗАЩЇ̈ ГРУПОВИХ ФОРМ ПІЗНАВАЛЬНОЇ ДІЯЛЬНОСТІ В УМОВАХ ВИЩОГО ПЕДАГОГІЧНОГО НАВЧАЛЬНОГО ЗАКЛАДУ
}

Дуднік А. О. Характеристика суб'єкта організації групових форм пізнавальної діяльності в умовах вищого педагогічного навчального закладу.

У статті розглянуто характеристику суб'єкта організації групових форм пізнавальної діяльності в умовах вищого педагогічного закладу, визначено специфіку організації групових форм пізнавальної діяльності студентів у вищих педагогічних навчальних закладах.

Ключові слова: готовність майбутнього вчителя, професійна діяльність, професійна компетентність, професійно-педагогічна підготовка.

Дудник A. O. Характеристика субъекта организации групповых форм познавательной деятельности в условиях высшего педагогического учебного заведения.

В статье рассмотрена характеристика субъекта организации групповых форм познавательной деятельности в условиях высшего педагогического заведения, определена специфика организации групповых форм познавательной деятельности студентов в высших педагогических учебных заведениях.

Ключевые слова: готовность будущего учителя, профессиональная деятельность, профессиональная компетентность, профессионально-педагогическая подготовка.

Dudnik A. O. The description of the subject of group forms of cognitive activity organization in higher pedagogical educational institutions.

The article dwells upon characteristics of a subject concerning group forms of cognitive activities organization in terms of higher pedagogical establishment, the specificity of group forms of students' cognitive organization in terms of higher pedagogical educational establishments has been also specified in the article.

Key words: a teacher's-to-be-readiness, professional activities, professional competence, professional-and-pedagogical training.

Інтеграція вищої освіти України до європейського та світового освітнього просторів актуалізує проблему вдосконалення професійної підготовки майбутнього педагога. Професійна діяльність учителя початкової школи в цілісному контексті педагогічної діяльності має свої особливості, зумовлені потребами і запитами цієї ланки освіти:

- визнання молодшого школяра суб' єктом навчальної діяльності;

- формування в учнів початкової школи ключових компетентностей, провідна серед яких - уміння вчитися, зокрема працювати в групах;

- створення умов для організації підготовки майбутніх учителів початкової школи до роботи з молодшими школярами.

Результатом підготовки студентів педагогічних факультетів до професійної діяльності $є$ готовність майбутніх учителів початкової школи до організації групових форм пізнавальної діяльності учнів [5, с. 64].

Мета статті: схарактеризувати суб'єкт організації групових форм пізнавальної діяльності в умовах вищого педагогічного навчального закладу. 
Освітній процес у вищому педагогічному навчальному закладі відрізняється від відповідних процесів в інших закладах освіти. Передусім, це зумовлено тим, що особистість студента вищого педагогічного навчального закладу - це особистість майбутнього вчителя, людини, яка протягом усієї своєї подальшої професійної діяльності буде мати безпосередній зв'язок із галуззю освіти, власне навчальним процесом, буде самостійно й безперервно поповнювати власний багаж знань i спонукатиме до подібної активної діяльності своїх учнів [4, с. 78].

Вище визначені положення доводять доцільність:

- звернення до особистості студента як суб'єкта організації групових форм пізнавальної діяльності в умовах вищого педагогічного навчального закладу;

- визначення й формулювання тих якостей особистості студента, які мають бути йому притаманні;

- вимог, які висуваються до студентів, задля ефективної організації й реалізації групових форм пізнавальної діяльності [1, с. 168].

Загальновідомим є факт, що категорія суб'єкта $є$ однією з центральних у філософії й особливо в онтології (Аристотель, Декарт, І. Кант, Г. Гегель та ін.).

Значний інтерес викликає визначена категорія й у сучасній психологічній науці (К. Абульханова-Славська, А. Брушлинський, В. Лекторський, О. Леонтьєв, С. Рубінштейн та ін.).

Суб'єкт освітньої діяльності охоплює дві взаємопов'язані форми - педагогічну й навчальну, тому розгляд окресленої проблеми пов'язаний як із загальнофілософським, так і з конкретнопедагогічним аспектом. Розглянемо специфіку організації групових форм пізнавальної діяльності студентів вищих педагогічних навчальних закладів [7].

По-перше, студент постає єдиним суб'єктом, який самостійно функціонує в процесі здійснення цієї діяльності, а саме: відсутні суб'єкт-суб'єктні взаємовідносини між ним і викладачем, хоча в організації групових форм пізнавальної діяльності, особливо на перших етапах перебування студента у вищому педагогічному навчальному закладі, викладач відіграє певну роль, але про суб'єкт-суб'єктні відносини в системі «викладач - студент» не йдеться.

По-друге, студент $з$ позиції майбутнього вчителя є одночасно й тим, хто навчає, а не лише тим, хто навчається. М. Лєвіна 3 цього приводу зазначає, що процес формування вчителя в педагогічному університеті має здійснюватись на грунті методологічного положення про особистість як суб'єкт діяльності та їі цілісність [3, c. 18].

Необхідно врахувати, що підготовка вчителя, керівництво процесом формування його особистості здійснюється через залучення студентів до функції вчителя й дослідника. Ці функції складають обов'язкову умову становлення грамотного, думаючого, творчого фахівця (В. Буряк, П. Гусак, І. Зязюн, Л. Кондрашова, М. Лєвіна, Н. Ничкало та ін.). I такі можливості також закладені в організації групових форм пізнавальної діяльності студентів у вищих педагогічних навчальних закладах.

Студент може виконувати роль учителя власне у групі, зокрема всі притаманні йому функції щодо планування, добору змісту, визначення ефективних форм, методів, засобів подачі навчального матеріалу, а також формування навичок аналізу, коригування, оцінювання, контролю групових форм діяльності. 3 іншого боку, саме в процесі організації групових форм пізнавальної діяльності студент має всі можливості до власного творчого пошуку й справжньої дослідницької роботи. Отже, залучення студентів до організації групових форм пізнавальної діяльності в умовах вищого педагогічного навчального закладу є запорукою плідного й позитивного переходу від виховання й освіти до самовиховання й самоосвіти [3, с. 13]. 
У педагогіці та психології вищої школи досліджується професійно-педагогічна підготовка майбутнього вчителя початкових класів як компетентного, здатного до саморозвитку: підготовка майбутнього вчителя початкових класів до роботи в умовах нової структури і змісту початкової освіти (Н. Бібік, О. Савченко), загальні принципи організації педагогічного процесу та основні напрями конструювання змісту психологопедагогічної підготовки, що забезпечують формування вчителя-дослідника, який перебуває в постійному пошуку ефективних i раціональних методів навчання i виховання (Л. Хомич), формування творчої особистості майбутнього вчителя (Н. Кічу, С. Сисоєва), організація професійного самовиховання майбутніх учителів початкових класів (О. Кучерявий), формування етичної компетентності майбутніх учителів початкових класів (Л. Хоружа) та ін.

Зосереджуючи увагу на визначенні та обгрунтуванні поняття «готовність учителя до організації групової навчальної діяльності учнів», ми грунтовно проаналізували дослідження Н. Кузьміної, А. Пєхоти, В. Сластьоніна та інших стосовно готовності майбутнього вчителя до професійної діяльності загалом.

Готовність майбутнього вчителя до професійної діяльності трактується науковцями (А. Капська, А. Лисенко, О. Пєхота та ін.) як особистісне утворення, що забезпечує внутрішні мотиви діяльності, педагогічну самосвідомість, педагогічні здібності, знання, вміння та навички, здатність до інтегрування знань, професійно значущі якості особистості. Воно містить особистісний складник (педагогічна самосвідомість, інтерес до діяльності, потреба в ній, мотиви діяльності) та процесуальний (педагогічні здібності, знання про предмет і способи діяльності, навички й уміння, професійно значущі якості) i мобілізує особистість на залучення до професійної діяльності.

Готовність майбутнього вчителя початкових класів до педагогічної діяльності грунтується на психологічній, педагогічній і предметній підготовці, що передбачає насамперед сформованість особистісних якостей педагога (І. Шапошникова).

Узагальнюючи підходи науковців до готовності як до результату професійнопедагогічної підготовки майбутнього вчителя, можна стверджувати, що готовність $€$ цілісним стійким утворенням і, на думку А. Лисенка, О. Пєхоти, С. Сисоєвої та ін., має низку позитивних якостей:

- грунтується на досвіді, легко актуалізується;

- $є$ стійкою, не потребує постійно нового формування у зв'язку з непередбаченою педагогічною ситуацією;

- $є$ динамічною, піддається розвитку і може досягати більш високих рівнів.

Готовність майбутнього вчителя до організації групових форм пізнавальної діяльності учнів визначаємо як частину професійної компетентності вчителя початкових класів i певний стан, який виникає внаслідок інтеграції мотивів, установок, психологічних якостей, професійно-педагогічних знань, умінь і навичок, досвіду 3 організації групових форм пізнавальної діяльності в багатопредметному середовищі початкової школи. Цілісність цього утворення зумовлюється повноцінним розвитком його складових компонентів (за О. Пєхотою): ціле-мотиваційний компонент (прагнення залучати молодших школярів до спільної діяльності, віра в можливості та здібності кожного учня; уміння усвідомлювати потреби і мотиви молодших школярів); змістовий (знання теоретичних основ організації групових форм пізнавальної діяльності; його психолого-педагогічного забезпечення; володіння методикою проведення уроків із застосуванням групових форм пізнавальної діяльності учнів із навчальних предметів початкової школи); операційний (уміння організовувати групові форми пізнавальної діяльності учнів; практичні дії 3 організації групового спілкування школярів); 
інтеграційний (уміння співпрацювати 3 різними партнерами в групі та команді, виконувати різні ролі й функції в колективі, виявляти ініціативу, підтримувати та керувати власними взаєминами 3 іншими; впевненість у власних професійних можливостях; ініціативність; відповідальність; володіння навичками саморефлексії самоаналізу, саморегуляції, самооцінки і самоконтролю, самоактуалізації).

Відповідно до вимог сучасного суспільства вчитель сьогодні має бути не лише професійно компетентним і творчо активним, а й конкурентоспроможним фахівцем, характерними рисами якого $є$ високий рівень самостійності, гнучкість мислення, здатність до педагогічної рефлексії та сформована потреба в самовдосконаленні. Конкурентоспроможність педагога залежить від рівня розвитку його мотиваційної, пізнавальної та соціальної сфер, чому значною мірою сприяє ефективно організована внутрішньо шкільна методична робота [6, с. 42].

\section{Лiтература}

1. Буряк В. К. Педагогічна культура: теоретико-методологічний аспект / Володимир Костянтинович Буряк. - К. : Деміург, 2005. - 232 с. 2. Кондрашова Л. В. Высшая педагогическая школа и Болонский процесс: реалии и перспективы / Лидия Валентиновна Кондрашова. - Кривой Рог: КДПУ, 1996. - 74 с. 3. Левина М. М. Технологии профессионального педагогического образования: [учеб. пособ. для студ. высш. учеб. заведений] / Марина Михайловна Левина. - М. : Академия, 2001. - 272 с. 4. Малихін О. В. Організація самостійної навчальної діяльності студентів вищих педагогічних навчальних закладів: теоретико-методологічний аспект:[монографія]/ Олександр Володимирович Малихін. - Кривий Ріг: Видавничий дім, 2009. - 307 с. 5. Ничкало Н. Г. Розвиток професійної освіти і навчання в контексті Свропейської інтеграції / Н. Г. Ничкало// Педагогіка і психологія. - 2008. - № 1. - С. 57-69. 6. Митник О. Розвиток конкурентоспроможності сучасного вчителя у межах внутрішньошкільної методичної роботи / Олександр Митник // Рідна школа. - 2013. №1-2. - С. 37-42. 7. Рубинштейн С. Л. Основы общей психологии / Сергей Львович Рубинштейн. - СПб. : Питер, 2003. - 720 с.

$$
\text { УДК - 81'1: [378+004] }
$$

Ольга Захарчук-Дуке

\section{ЕЛЕКТРОННИЙ ПІРУЧНИК ЯК ОБ'ЄКТ ТЕОРЕТИЧНОГО АНАЛІЗУ В ЛІНГВІСТИЦІ ТА ЛІНГВОДИДАКТИЦІ ВИЩОЇ ШКОЛИ}

Захарчук-Дуке О. О. Електронний підручник як об'єкт теоретичного аналізу в лінгвістиці та лінгводидактиці вищої школи.

У статті проаналізовано різні формулювання поняття «електронний підручник», висвітлено переваги електронного підручника порівняно 3 лінійним, обгрунтовано доцільність роботи студентів з електронним підручником на заняттях у вищій школі в умовах Болонського процесу.

Ключові слова: Болонський процес, інформаційне суспільство, електронний підручник, гіпертекст, мультимедія.

Захарчук-Дуке О. О. Электронный учебник как объект теоретического анализа в лингвистике и лингводидактике высшей школы.

В статье проанализированы разные формулировки понятия «электронный учебник», описаны преимущества электронного учебника над линейным, обоснована целесообразность работы студентов с электронным учебником на занятиях в высшей школе в условиях Болонского процеса. 